\title{
Modeling of thin layer drying characteristics of “Xiem" banana peel cultivated at U Minh district, Ca Mau province, Vietnam
}

\author{
Tai, N.V., Linh, M.N. and ${ }^{*}$ Thuy, N.M. \\ Department of Food Technology, College of Agriculture, Can Tho University, Can Tho city, Vietnam
}

\author{
Article history: \\ Received: 14 March 2021 \\ Received in revised form: 22 \\ April 2021 \\ Accepted: 13 June 2021 \\ Available Online: 30 October \\ 2021
}

\section{Keywords:}

Modelling,

Kinetic,

"Xiem" banana,

Oven drying,

Temperature

DOI:

https://doi.org/10.26656/fr.2017.5(5).180

\begin{abstract}
In Vietnam, banana peels have been discarded as waste which is a potential source of raw material for food and other bioprocessing industries. Drying the peel offers opportunities for value addition into novel products, thus reducing waste from the fruit processing operations. This study presented the mathematical models of the thin-layer drying behaviour of banana peels using three air temperatures $\left(60^{\circ} \mathrm{C}, 70^{\circ} \mathrm{C}\right.$ and $\left.80^{\circ} \mathrm{C}\right)$. The effect of drying temperature on the reduction of moisture content and drying rate of the banana peel was evaluated. A total of eight commonly drying models were used for choosing the best fitness model for describing the oven drying process. The effective moisture diffusivity and activation energy were calculated using Fick's diffusion equation. The obtained results showed that increasing drying temperature accelerate the drying process, as well as, increasing drying rate and effective diffusivity. The goodness of fit tests base on the criterion indicated that the Page model gave the best fit to experimental results. The effective diffusivity varied from $2.29 \times 10^{-8}-3.25 \times 10^{-8} \mathrm{~m}^{2} / \mathrm{s}$. Effective diffusivity was satisfactorily by an Arrhenius relationship with activation energy within the $60-80^{\circ} \mathrm{C}$ temperature range. The obtained activation energy was $16.98 \mathrm{~kJ} / \mathrm{mol}$ with a high coefficient of determination $\left(\mathrm{R}^{2}=0.903\right)$.
\end{abstract}

\section{Introduction}

In recent years, fruit and vegetable by-products constitute a big and very problematic portion of these byproducts because of their high specific volume and moisture content. The peels/seeds from fruit and vegetable are regarded as wastes. By using appropriate processing techniques, these wastes could be used to make valuable by-products (Schieber et al., 2001). Based on the $3 \mathrm{R}$ (reduce, reuse and recycle) principle, these materials cannot be regarded as wastes but they can become an additional valuable resource to augment existing natural materials. For economic purposes, taking advantage of by-products to process food products is more valuable, rather than their discharge to the environment which causes detrimental environmental effects.

Bananas (Musa sp.) are one of the most common and important tropical fruits consumed worldwide. Moreover, it is generally grown in all types of land available in Vietnam which turns it as an important economic crop. Nutritionally, bananas contain many important nutritional compounds as available carbohydrates which provide energy, vitamins B and C, and significant amounts of potassium and magnesium and amino acids. Banana peels account for only $30 \%$ of the total fruit weight and have $20 \%$ dry matter, however, in the food processing industry, a large amount of banana peels has been discarded as waste into the environment and have a negative impact on the surrounding living place (Shadma et al., 2014). This resulted in a hundred tons of waste from banana peels generated each day and this amount tends to increase annually. However, it contains minerals, various amino acids, antioxidant compounds and also contains a significant amount of carbohydrates, proteins, and fiber, making it an ideal substrate for the production of value-added product (Aghbashlo et al., 2008; Demir et al., 2004). In some recent research, extracts of the banana peel possess potential antimicrobial activity against several microorganisms likely Staphylococcus aureus, Streptococcus pyogenes, Enterobacter aerogenes, Escherichia coli (Chabuck et al., 2013). So, the problem can be recovered by utilizing its high-added value compounds from these materials, including the antioxidant compound and the dietary fibre fraction that have a great potential in the preparation of functional 
foods (Wachirasiri et al., 2009). Banana peel can be used to make noodles by partial substitution of wheat flour with banana peel flour. With a high amount of dietary fibre, the banana peel has the potential to slow the rate of starch hydrolysis in yellow noodles (Ramli et al., 2009).

Several technological treatments are applied to utilize the waste from these peels, drying is one of the best and fast ways to generate a value add product, which could be an initial treatment process to solve a large amount of these peels. Drying not only extends the life of raw materials with a high moisture content but also can minimize the costs of handling and distribution (Chen and Mujumdar, 2009). In the principle of drying operation, the heat and mass transfer processes occur simultaneously where heat penetrates the food product and causes the transfer of moisture from within the food to its surface with subsequent evaporation to the air stream as vapour. Mathematical modelling of the thin layer drying process is important for managing operating conditions during the drying process and for predicting the performance of a drying process of the product. Oven drying is an economically feasible method of drying and is convenient for plant material (Chen and Mujumdar, 2009). In view of the health-promoting properties and high nutritional benefits of banana peel, the current study was conducted to obtain the effect of various temperatures $\left(60-80^{\circ} \mathrm{C}\right)$ on drying characteristics of banana peel and to select the best mathematical model in achieving the drying behaviour of the peel.

\section{Materials and methods}

\subsection{Sample preparation}

Bananas at the colour index of 1 (mature green) according to the CSIRO banana ripening guide were purchased from $\mathrm{U}$ Minh district, $\mathrm{Ca}$ Mau province, Vietnam. The fruits were thoroughly washed with tap water to remove adhered earth and foreign materials and then, separated into pulp and peel. The fresh banana peel was cut in the dimension of $118 \pm 1.0 \mathrm{~mm}$ (length), $10 \pm 0.1 \mathrm{~mm}$ (width) and $2.0 \pm 0.1 \mathrm{~mm}$ (thickness) were used. Then, they were soaked in sodium metabisulfite solution $(500 \mathrm{ppm})$ and were spread into stainless steel trays. Before starting the drying experiment, the initial moisture content was measured using a modified AOAC method 925.45 (2005). All the drying tests were run two times in triplicates at each temperature and averages were reported.

Three different temperature levels $\left(60,70\right.$ and $\left.80^{\circ} \mathrm{C}\right)$ were used and the oven dryer (Model SIBATA SD-60, Japan) was operated at an air velocity of $1.0 \mathrm{~m} / \mathrm{s}$, parallel to the drying surface of the sample. Weight change was recorded by a digital balance (Ohaus, SR series, America, $d=0.001$ ) at an hourly interval during drying. Peels were dried until equilibrium was reached.

\subsection{Mathematical modelling of banana peel}

The moisture ratio (MR) of banana peels during the drying process was obtained following Equation 1.

$\mathrm{MR}=\frac{\mathrm{M}_{\mathrm{t}}-\mathrm{M}_{\mathrm{e}}}{\mathrm{M}_{\mathrm{o}}-\mathrm{M}_{\mathrm{e}}}$

Where $M_{t}, M_{o}$ and $M_{e}$ are moisture content at each measurement time, initial moisture content, and equilibrium moisture content $(\mathrm{kg}$ water $/ \mathrm{kg}$ dry matter) respectively. However, the drying varied continuously during the drying experiments, the relative moisture content of drying air is simplified into Equation 2 (Akpinar et al., 2003):

$\mathrm{MR}=\frac{\mathrm{M}_{\mathrm{t}}}{\mathrm{M}_{0}}$

Several researchers have predicted semi-theoretical and empirical models describing the kinetic behaviour of the thin-layer drying process. Eight thin-layer drying models were fitted to the drying curves so as to select the best model suitable for describing the drying curve of banana peels (Erbay and Icier, 2009). The models are presented in Table 1.

\subsection{Nonlinear regression analysis}

Nonlinear regression analysis was used to evaluate the parameters of the selected model using the statistical software Statgraphics Centurion XV.I (USA). As a primary criterion to select the best equation, the root mean square error (RMSE), coefficient of determination $\left(\mathrm{R}^{2}\right)$ and chi-square $\left(\chi^{2}\right)$ were determined and used as the primary criterion to select the best equation to account for variation in the drying curves of the dried samples (Ertekin and Yaldiz, 2004). The highest values of $\mathrm{R}^{2}$ and the lowest values of $\chi^{2}$ and RMSE values were used to determine the best fit. These statistical values can be calculated as following Equation 3-5, respectively.

Table 1. Selected thin layer drying models for describing the drying characteristic of purple shallot

\begin{tabular}{llcl}
\hline \multicolumn{1}{c}{ Models } & \multicolumn{1}{c}{ Equation } & Models & \multicolumn{1}{c}{ Equation } \\
\hline Lewis & MR $=\mathrm{e}^{(-\mathrm{kt})}$ & Logarithmic & $\mathrm{MR}=\mathrm{ae}^{(-\mathrm{kt})}+\mathrm{c}$ \\
Henderson and Pabis & $\mathrm{MR}=\mathrm{ae}^{(-\mathrm{kt})}$ & Midilli & $\mathrm{MR}=\mathrm{ae}^{(-\mathrm{kt})}+\mathrm{bt}$ \\
Page & $\mathrm{MR}=\mathrm{e}^{\left(-\mathrm{k}\left(\mathrm{t} \mathrm{t}^{\mathrm{n}}\right)\right.}$ & Two-term exponential & $M R=\mathrm{ae}^{(-\mathrm{kt})}+(1-\mathrm{a}) e^{(-k a t)}$ \\
Wang and Smith & $\mathrm{MR}=1+\mathrm{at}+\mathrm{bt}^{2}$ & Two-term & $\mathrm{MR}=\mathrm{ae}^{\left(-\mathrm{k}_{1} \mathrm{t}\right)}+\mathrm{be}^{\left(-\mathrm{k}_{2} \mathrm{t}\right)}$ \\
\hline
\end{tabular}




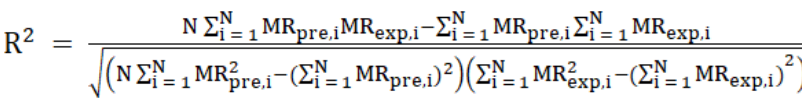

$\mathrm{RMSE}=\left[\frac{1}{\mathrm{~N}} \sum_{\mathrm{i}=1}^{\mathrm{N}}\left(\mathrm{MR}_{\text {pre }, \mathrm{i}}-\mathrm{MR}_{\text {exp }, \mathrm{i}}\right)^{2}\right]^{1 / 2}$

$\chi^{2}=\frac{\sum_{\mathrm{i}=1}^{\mathrm{N}}\left(\mathrm{MR}_{\text {pre }, \mathrm{i}}-\mathrm{MR}_{\text {exp, } \mathrm{i}}\right)^{2}}{\mathrm{~N}-\mathrm{n}}$

where $M_{\text {exp,i }}$ and $M_{\text {pre, }}$ is the experimental and predicted moisture ratio at observation $\mathrm{i} ; \mathrm{N}$ is the number of the experimental data points, and $\mathrm{n}$ is the number of constants in the model.

\subsection{Determination of the effective moisture diffusivity (Deff)}

Diffusivities are typically determined by plotting experimental drying data in terms of $\ln$ MR versus drying time $(t)$, because the plot gives a straight line with a slope as follows Equation 6.

Slope $=\frac{\pi^{2} D_{\text {eff }}}{4 L^{2}}$

where $t$ is the time (s), $D_{\text {eff }}$ is the effective diffusivity $\left(\mathrm{m}^{2} / \mathrm{s}\right)$ and $\mathrm{L}$ is the thickness of samples $(\mathrm{m})$.

The relationship between effective diffusivity and drying temperature can be predicted appropriately using the Arrhenius equation (Akpinar et al., 2003). The activation $\left(\mathrm{E}_{\mathrm{a}}\right)$ can be determined using Equation 7 .

$D_{\text {eff }}=D_{0} \exp \left(\frac{-E a}{R T}\right)$

where $D_{0}$ is is the pre-exponential factor of the Arrhenius equation $\left(\mathrm{m}^{2} / \mathrm{s}\right), \mathrm{E}_{\mathrm{a}}$ is the activation energy in $\mathrm{KJ} / \mathrm{mol}$, T is the absolute drying air temperature $(\mathrm{K})$ and $\mathrm{R}$ is the universal gas constant $(8.314 \mathrm{~J} / \mathrm{mol} . \mathrm{K})$.

\section{Results and discussion}

\subsection{Drying characteristics}

The moisture content ( $\%$ dry weight basis, $(\%$ dwb)) were calculated from the change in the sample's weight during the drying process, which occurred in each consecutive time interval. A single layer of banana peel samples was dried in the hot air oven drier at the temperature of 60,70 and $80^{\circ} \mathrm{C}$. Figure 1 shows the graph of moisture content versus time for banana peels samples. As shown, the average initial moisture content of banana peel was $1122.358 \pm 2.539(\% \mathrm{dwb})$ and drying time for all the samples ranged between 4 and 6 hours. The samples had a thickness of approximately $2 \mathrm{~mm}$ were dried to the final moisture content of $7.68,7.37$ and $7.56(\% \mathrm{dwb})$ using an oven drier at 60,70 and $80^{\circ} \mathrm{C}$, respectively. The temperature of $80^{\circ} \mathrm{C}$ required a shorter drying time in comparison with $60^{\circ} \mathrm{C}$. In other words, the time of drying was reduced to approximately $33 \%$ for $80^{\circ} \mathrm{C}$ in comparison with $60^{\circ} \mathrm{C}$. The drying time decreased as the drying temperature increased because of the relatively higher resistance to moisture movement at low temperatures than at higher ones. According to Kaya et al. (2007), the resistance of the food structure is known to decrease the drying rate, which resulted in the increased drying time of 60 and $70^{\circ} \mathrm{C}$. Moreover, increasing the temperature of drying decreased the total time of drying as the heat transfer was increased due to the increasing temperature, in other words, drying at a higher temperature implies a larger driving force for heat transfer (Kaya et al., 2007).

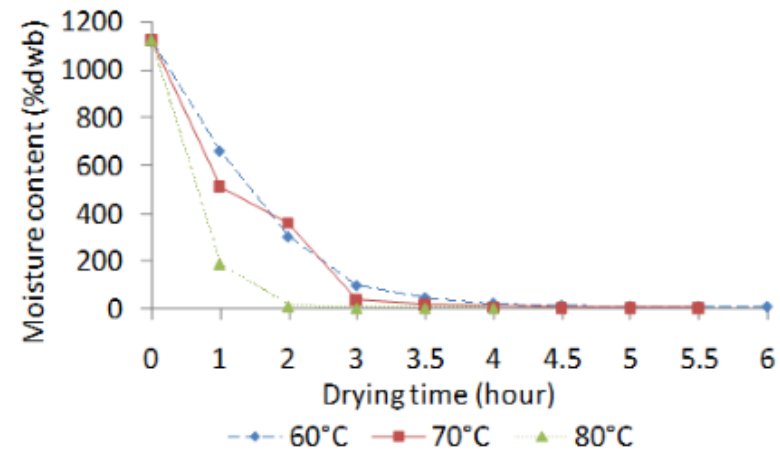

Figure 1. Drying curves of banana peels at different temperatures

The moisture content of the samples decreased at temperatures of 60,70 and $80^{\circ} \mathrm{C}$ with a variation drying rate which exhibits a falling rate of drying which is the main drying mechanism in controlling the water evaporation rate. The higher drying time required to remove the moisture content in the banana peels could be a result of the slow diffusion process. Moreover, a decrease in the drying time as the temperature increases is attributed to the increased thermal energy, which increases the rate of water molecules that transfer in the food matrix (Maskan et al., 2002). This result correlates with previous studies reported for various food materials such as Vietnamese shallot (Thuy et al., 2020), culinary banana slices (Khawas et al., 2014), and India blanched banana peel (Kumar, 2015). Figure 2 illustrates the changes in moisture ratio against drying time of banana peels at three different oven-drying temperatures. The drying rate decreased continuously during the drying period. The continuous decrease in moisture ratio indicates that diffusion has governed the internal mass

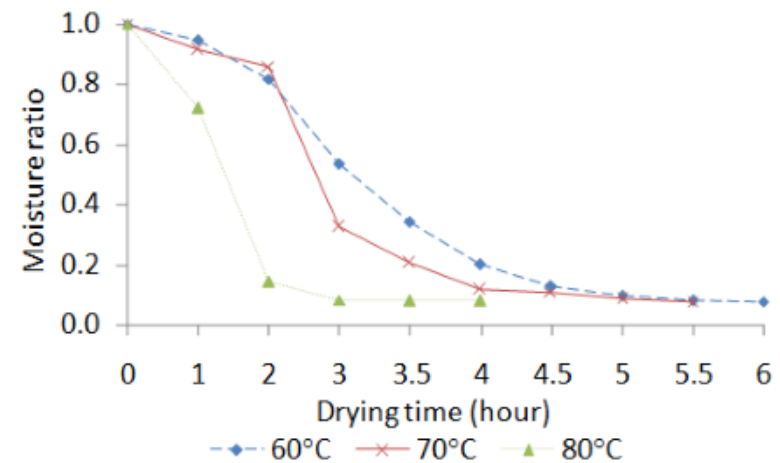

Figure 2. Drying characteristic curve of banana peels at different temperatures 
Table 2. Thin-layer models applied to the drying curves at different drying temperatures

\begin{tabular}{|c|c|c|c|c|c|}
\hline Model & Temperature $\left({ }^{\circ} \mathrm{C}\right)$ & Model constants & RSME & $\mathrm{R}^{2}(\%)$ & $\chi^{2}$ \\
\hline \multicolumn{6}{|l|}{ Lewis } \\
\hline & 60 & $\mathrm{k}=0.3025$ & 0.1468 & 99.00 & 0.0239 \\
\hline & 70 & $\mathrm{k}=0.3454$ & 0.1669 & 82.13 & 0.0310 \\
\hline & 80 & $\mathrm{k}=0.6490$ & 0.1099 & 92.64 & 0.0134 \\
\hline \multicolumn{6}{|c|}{ Logarithmic } \\
\hline & 60 & $\mathrm{a}=2.1152 ; \mathrm{k}=0.1230 ; \mathrm{c}=-0.9987$ & 0.1035 & 94.05 & 0.0153 \\
\hline & 70 & $\mathrm{a}=2.7990 ; \mathrm{k}=0.0927 ; \mathrm{c}=-1.7046$ & 0.1389 & 90.72 & 0.0275 \\
\hline & 80 & $\mathrm{a}=1.1681 ; \mathrm{k}=0.5146 ; \mathrm{c}=-0.1281$ & 0.1300 & 93.82 & 0.0242 \\
\hline \multicolumn{6}{|c|}{ Wang and Sign } \\
\hline & 60 & $\mathrm{a}=-0.1710 ; \mathrm{b}=-0.000097$ & 0.1015 & 93.46 & 0.0129 \\
\hline & 70 & $a=-0.2053 ; b=0.0034$ & 0.1350 & 89.76 & 0.0228 \\
\hline & 80 & $a=-0.5054 ; b=0.0679$ & 0.0995 & 95.18 & 0.0124 \\
\hline \multicolumn{6}{|c|}{ Henderson and Pabis } \\
\hline & 60 & $\mathrm{a}=1.1548 ; \mathrm{k}=0.3422$ & 0.1410 & 87.38 & 0.0249 \\
\hline & 70 & $\mathrm{a}=1.1469 ; \mathrm{k}=0.3863$ & 0.1661 & 84.51 & 0.0345 \\
\hline & 80 & $\mathrm{a}=1.0518 ; \mathrm{k}=0.6735$ & 0.1198 & 93.01 & 0.0179 \\
\hline \multicolumn{6}{|l|}{ Midilli } \\
\hline & 60 & $\mathrm{a}=1.087 ; \mathrm{k}=0.1010 ; \mathrm{c}=-0.0981$ & 0.1009 & 94.35 & 0.0145 \\
\hline & 70 & $\mathrm{a}=1.090 ; \mathrm{k}=0.1521 ; \mathrm{c}=0.0911$ & 0.1397 & 90.61 & 0.0279 \\
\hline & 80 & $\mathrm{a}=1.041 ; \mathrm{k}=0.5731 ; \mathrm{c}=-0.0205$ & 0.1318 & 93.66 & 0.0248 \\
\hline \multicolumn{6}{|c|}{ Two-term } \\
\hline & 60 & $\mathrm{a}=0.096 ; \mathrm{b}=0.248 ; \mathrm{k}_{1}=0.344 ; \mathrm{k}_{2}=0.336$ & 0.1628 & 87.38 & 0.0442 \\
\hline & 70 & $\mathrm{a}=0.877 ; \mathrm{b}=0.268 ; \mathrm{k}_{1}=0.382 ; \mathrm{k}_{2}=0.396$ & 0.1966 & 84.51 & 0.0644 \\
\hline & 80 & $\mathrm{a}=0.957 ; \mathrm{b}=0.094 ; \mathrm{k}_{1}=0.671 ; \mathrm{k}_{2}=0.688$ & 0.1694 & 93.00 & 0.0487 \\
\hline \multicolumn{6}{|c|}{ Two-term exponential } \\
\hline & 60 & $\mathrm{a}=2.4251 ; \mathrm{k}=0.5499$ & 0.0712 & 96.79 & 0.0063 \\
\hline & 70 & $\mathrm{a}=0.9826 ; \mathrm{k}=0.3460$ & 0.1784 & 82.13 & 0.0398 \\
\hline & 80 & $\mathrm{a}=0.9999 ; \mathrm{k}=0.6461$ & 0.1229 & 92.64 & 0.0189 \\
\hline \multicolumn{6}{|l|}{ Page } \\
\hline & 60 & $\mathrm{k}=0.0386 ; \mathrm{n}=2.6074$ & 0.0375 & 98.89 & 0.0018 \\
\hline & 70 & $\mathrm{k}=0.0329 ; \mathrm{n}=3.0390$ & 0.0740 & 96.16 & 0.0068 \\
\hline & 80 & $\mathrm{k}=0.3385 ; \mathrm{n}=2.4228$ & 0.0786 & 94.12 & 0.0077 \\
\hline
\end{tabular}

transfer. A higher drying air temperature decreased the moisture ratio faster due to the increase in air heat supply rate to banana peel and the acceleration of moisture migration (Demir et al., 2004).

\subsection{Modelling of drying curves}

The data of moisture content obtained from the drying process of banana peels at three levels of airdrying temperature was calculated to moisture ratio and was fitted to eight thin-layer drying models. The achieved results are presented in Table 2 along with the statistical analysis of the model included the coefficient of correlation, the root mean square error and Chisquare. According to Demir et al. (2004) reported that the best model to explain the thin layer drying characteristic of the banana peel was chosen based on some selection criteria's as the highest correlation coefficient $\left(\mathrm{R}^{2}\right)$, least of the root mean square error (RMSE) and least of the reduced $\chi^{2}$ values (Demir et al., 2004). As shown in Table 2, the values of the $\mathrm{R}^{2}$, RMSE and $\chi^{2}$ for eight drying models and three levels of drying temperatures $\left(60-80^{\circ} \mathrm{C}\right)$ ranged from 81.13 to $99.00 \%$, 0.0375 to 0.1966 and 0.0018 to 0.0644 , respectively.
Based on these results, the model that best fit the experimental data using the previously stated criterion for drying at $60^{\circ} \mathrm{C}$ was the Lewis model whereas that at 70 and $80^{\circ} \mathrm{C}$ was the Page model. However, when the sample was dried at $60^{\circ} \mathrm{C}$, the result of the correlation coefficient of the Lewis model is not significantly different in comparison with the Page model. According to these results, the best fitness model to predict the thinlayer drying behaviour of the "Xiem" banana peel was the Page model. Figure 3 shows conformity between the experimental and predicted moisture ratio values as they both laid around straight for the Page model with the high correlation coefficient $(0.983)$. The moisture ratio of the banana peels at different stages of drying could be predicted successfully using the following Equation 810.

For drying at $60^{\circ} \mathrm{C}$ : MR $=\exp \left(-0.0386 \mathrm{t}^{2.6074}\right)$, $\mathrm{R}^{2}=98.89$, RMSE $=0.0375, \chi^{2}=0.0018$

For drying at $70^{\circ} \mathrm{C}: \mathrm{MR}=\exp \left(-0.0329 \mathrm{t}^{3.0390}\right)$,

$\mathrm{R}^{2}=96.16, \mathrm{RMSE}=0.0740, \chi^{2}=0.0068$

For drying at $80^{\circ} \mathrm{C}: \mathrm{MR}=\exp \left(-0.3385 \mathrm{t}^{2.4228}\right)$, $\mathrm{R}^{2}=94.12, \mathrm{RMSE}=0.0786, \chi^{2}=0.0077$ 


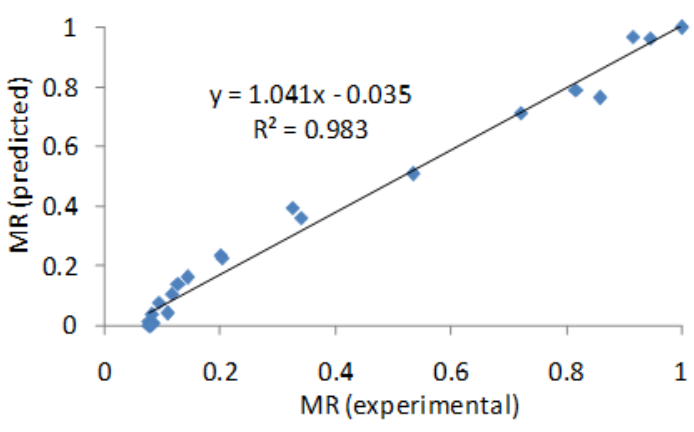

Figure 3. Plot of experimental moisture against predicted moisture ratio by Page model

\subsection{The effective moisture diffusivity}

Analysis of the falling rate period was performed to understand the drying kinetics and to determine the effective moisture diffusivity ( $\left.\mathrm{D}_{\text {eff }}\right)$ by slope method and this reviews that the mass transfer during drying operations is controlled by internal diffusion (Babalis and Belessiotis, 2004). The obtained result revealed that drying at $60^{\circ} \mathrm{C}$ had the lowest $\mathrm{D}_{\text {eff }}$ value of $2.29 \times 10^{-8}$ while drying at $80^{\circ} \mathrm{C}$ had the highest value of $\mathrm{D}_{\text {eff }}$ $\left(3.25 \times 10^{-8}\right)$. In general, $\mathrm{D}_{\text {eff }}$ increases with an increase in drying temperature, thus temperature has a positive influence on moisture diffusivity. This variation in values could be attributed to a difference in location and growth condition, levels of maturity, drying equipment and other parameters that cannot be controlled. The study of Doymaz (2010) also reported an increase in moisture diffusivity of banana (Cavendish) slices with an increased drying temperature.

\subsection{Activation energy}

The activation energy which is the minimum energy required to initiate moisture diffusion from the food products is obtained by the Arrhenius equation for the banana peels drying data at various air-drying temperatures. Plotting the graph of In $D_{\text {eff }}$ against the inverse of absolute temperature as revealed in Figure 4 shows a slightly high correlation of 0.903 indicating a good fit. The value of the activation energy obtained in this study was $16.98 \mathrm{~kJ} / \mathrm{mol}$. The value obtained is however lower when compared with the value reported by Doymaz (2010) for banana slices. The differences

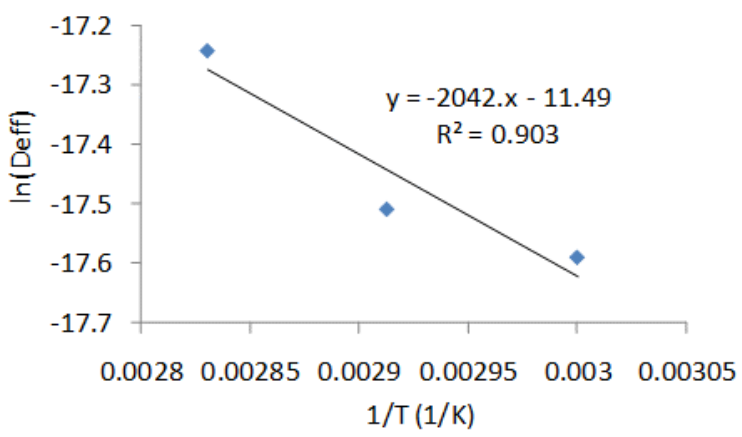

Figure 4. Arrhenius type relationship between effective moisture diffusivity and temperature observed could be related to a higher temperature (i.e. 60 $-85^{\circ} \mathrm{C}$ ) used in their study.

\section{Conclusion}

Drying kinetics curves of drying banana peel demonstrated that drying at $60-80^{\circ} \mathrm{C}$ were the optimum values for drying banana peel with the appropriate equations using the Page model. The research was initially carried out to solve the great amount of banana peels released into the environment. Moreover, the obtained banana peel powder from this research would be possible to utilize as a functional ingredient in starchrich products such as noodles or nutritional powder.

\section{Conflict of interest}

The authors declare no conflict of interest.

\section{Acknowledgements}

The authors acknowledge the financial support to Can Tho University, Vietnam from the Research fund project code number T2020-67.

\section{References}

Aghbashlo, M., Kianmehr, M.H. and Samimi, A.H. (2008). Influence of drying conditions on the effective moisture diffusivity energy of activation and energy consumption during the thin-layer drying of barberries fruit (Berberidaceae). Energy Conversion and Management, 49(10), 2865-2871. https://doi.org/10.1016/j.enconman.2008.03.009

Akpinar, E., Midilli, A. and Bicer, Y. (2003). Singlelayer drying behaviour of potato slices in a convective cyclone dryer and mathematical modelling. Energy Conversion and Management, 44 (10), 1689-1705. https://doi.org/10.1016/S0196-8904 (02)00171-1

AOAC (Association of Official Analytical Chemists). (2005). Official methods of analysis of the Association of Analytical Chemists International. USA: AOAC.

Babalis, S.J. and Belessiotis, V.G. (2004). Influence of the drying conditions on the drying constants and moisture diffusivity during the thin-layer drying of figs. Journal of Food Engineering, 65(3), 449-458. https://doi.org/10.1016/j.jfoodeng.2004.02.005

Chabuck, Z.A.G., Al-Charrakh, A.H., Hindi, N.K.K. and Hindi, S.K.K. (2013). Antimicrobial effect of aqueous banana peel extract. Research Gate: Pharmaceutical Sciences, 1, 73-75. 
Chen, X.D. and Mujumdar, A.S. (Eds.). (2009). Drying technologies in food processing. United Kingdom: John Wiley and Sons.

Demir, V., Gunhan, T., Yagcioglu, A.K. and Degirmencioglu, A. (2004). Mathematical modeling and the determination of some quality parameters of air-dried bay leaves. Biosystems Engineering, 88(3), 325-335. https://doi.org/10.1016/ j.biosystemseng.2004.04.005

Doymaz, İ. (2010). Evaluation of mathematical models for prediction of thin-layer drying of banana slices. International Journal of Food Properties, 13(3), 486 -497. https://doi.org/10.1080/10942910802650424

Erbay, Z. and Icier, F. (2009). A review of thin layer drying of foods: theory, modeling, and experimental results. Critical Reviews in Food Science and Nutrition, 50(5), 441-464. https:// doi.org/10.1080/10408390802437063

Ertekin, C. and Yaldiz, O. (2004). Drying of eggplant and selection of a suitable thin layer drying model. Journal of Food Engineering, 63(3), 349-359. https://doi.org/10.1016/j.jfoodeng.2003.08.007

Kaya, A., Aydin, O., Demirtas, C. and Akgun M. (2007). An experimental study on the drying kinetics of quince. Desalination, 212(1-3), 328-343. https:// doi.org/10.1016/j.desal.2006.10.017

Khawas, P., Das, A.J., Dash, K.K. and Deka, S.C. (2014). Thin-layer drying characteristics of Kachkal banana peel (Musa ABB) of Assam. International Food Research Journal, 21(3), 1011-1118.

Kumar, S.K. (2015). Drying kinetics of banana peel. Journal of Food Processing and Technology, 6 (11), 10-12. https://doi.org/10.4172/21577110.1000514

Maskan, A., Kaya, S. and Maskan, M. (2002). Hot Air and Sun Drying of Grape Leather (pestil). Journal of Food Engineering, 54(1), 81-88. https:// doi.org/10.1016/S0260-8774(01)00188-1

Ramli, S., Alkarkhi, A.F.M., Yong, Y.S. and Easa, A.M. (2009). Utilization of banana peel as a functional ingredient in yellow noodle. Asian Journal of Food and Agro-Industry, 2(3), 321-329.

Schieber, A., Stintzing, F. C. and Carle, R. (2001). Byproducts of plant food processing as a source of functional compounds-recent developments. Trends in Food Science and Technology, 12(11), 401-413. https://doi.org/10.1016/S0924-2244(02)00012-2
Shadma, A., Sundaram, S. and Rai, G.K. (2014). Nutraceutical application and value addition of banana peel: A review. International Journal of Pharmacy and Pharmaceutical Sciences, 6(10), 81-85.

Thuy, N.M., Tuyen, N.T.M., Thanh, N.V. and Tai, N.V. (2020). Evaluation of freeze-drying conditions on the process kinetics and physicochemical properties of purple shallot. Food Research, 4(5), 1630-1636. https://doi.org/10.26656/fr.2017.4(5).246

Wachirasiri, P., Julakarangka, S. and Wanlapa, S. (2009). The effects of banana peel preparations on the properties of banana peel dietary fibre concentrate. Songklanakarin Journal of Science and Technology, 31(6), 605-611. 